\title{
Profile of Changes in Pedagogical Content Knowledge of Biology Teacher Candidates Based on Gender
}

\author{
Z. Abidin ${ }^{1}$, A.F. Hindiriana ${ }^{2}$, L. Lismaya ${ }^{3}$, E. Junaedi ${ }^{4}$ \\ Biology Education Studies Program University of Kuningan, West Java, Indonesia \\ \{zaenal.abidin@uniku.ac.id\}
}

\begin{abstract}
This study aims to analyze the profile of changes in pedagogical content knowledge of biology teacher candidates based on gender. This research applies descriptive qualitative research methods. The sample of this research is students of the Biology Education Study Program at a private university in West Java who have complete data or follow all research instruments, which are $80(77.7 \%)$ of the population of 103 students consisting of 65 (81.25\%) women and 15 (18.75\%) men. Sampling using purposive technique and saturated samples. The instruments used in the study were the CK, PK, and PCK knowledge test sheets, concept map test sheets and questionnaire sheets. The data analysis used descriptive qualitative data analysis. The results showed: the profiles of changes in the PCK of male and female Biology teacher candidates have the same pattern of change, which is not linear with the number of semesters that have been taken. Both end in almost complete mastery of PCK when prospective teachers are in their eighth semester. Male Biology teacher candidate PCK has higher PCK than female PCK. The rate of change in the PCK of male Biology teacher candidates is faster than that of women. Changes in PCK for female teacher candidates are more consistent and regular than for men who have unequal changes. This research is able to reveal the profile of changes in the PCK of Biology teacher candidates so that it can be used by LPTK as a reference in coaching and professional development of Biology Teacher Candidates including changing the curriculum.
\end{abstract}

Keywords: Implementation; Education; Character

\section{Introduction}

PCK is a skill possessed by a teacher when the teacher carries out his professional duties which is a representation of a mixture of Content Knowledge (CK) and Pedagogical Knowledge (PK) into an understanding of how certain topics, problems or issues are organized, presented, and adapted according to the needs and abilities of students and presented in learning [1]. PCK is an answer to a question that has been developing among academics and education practitioners, namely, what abilities should a teacher have when the teacher is doing his professional work in front of the class?

Research on PCK to date has produced thousands of journals, such as if we enter pedagogical content knowledge in the ERIC data base, there will be 8.400 journals or papers on PCK. However, if we enter PCK relation to gender there will be 5.548 and if we study the existing journals, the journals that really study PCK related to gender are still minimal, especially those related to changes in PCK for Biology teacher candidates. Research will be more interesting about how the PCK changes based on gender if it is related to the fact that the number of Biology teacher candidates is less $(25 \%)$ than female teacher candidates at each 
level in the tertiary institutions where the research was conducted. The results of previous research on changes in PCK for prospective teachers showed: 1) PCK is not only knowledge but also skill so it requires multiple assessments to uncover it; 2) PCK as knowledge has a pattern of change that is not linear with the number of semesters that have been taken by prospective teacher students, in contrast to PCK as a skill [2].

\section{Method}

This research uses a descriptive method. Descriptive research was carried out by using variables in accordance with what happened in the field which were usually explained either by sentences or numbers. Quantitative data is used to obtain an overview of the pattern of PCK changes, individual knowledge (CK and PK) and the level of mastery of the Biology teacher candidate concept map even semester of the 2018/2019 academic year. Qualitative data is used to obtain more data about the three patterns of change. The sample in this study were Biology Education students at a private tertiary institution in West Java who participated in the study and followed all research instruments and had complete data, namely 22 second semester students (19 girls, 3 boys), fourth semester 18 people (14 women, 4 men), 19 (14 women and 5 men) in the sixth semester and 21 (18 women and 3 men) in the eighth semester so that the number of valid samples was $80(77.7 \%)$ of a population of 103 students. The instruments used for PCK data were knowledge tests and concept maps; instruments for individual knowledge using CK and PK tests which were previously tested for validity and reliability and validated by biologists, pedagogics and instrument experts. Interview guide sheet for prospective teachers.

\section{Result and Discussion}

Changes in PCK for Biology teacher candidates based on gender as measured by pedagogical content (CK), pedagogical knowledge (PK) and PCK between women and men were not different. Changes in CK for male and female teacher candidates are linear, namely the more the number of semesters taken, the higher the level of mastery of CK. Changes in PK and PCK for male and female teacher candidates are not linear, namely the increase in the number of semesters taken is not followed by the increase in PCK for prospective teachers. The pattern of changes in CK, PK and PCK based on gender can be seen in Figure 1.

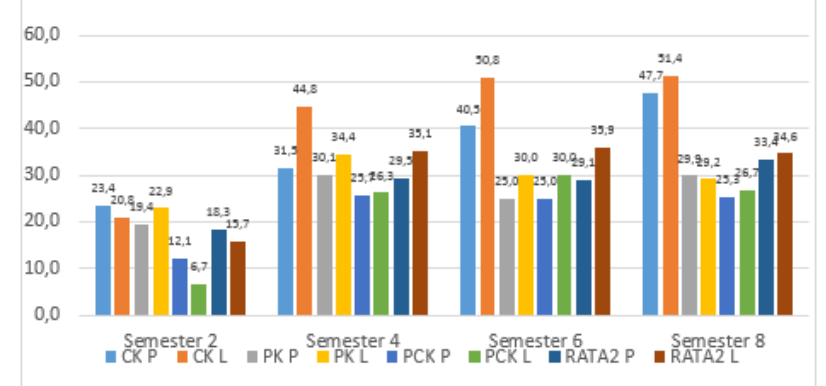

Fig 1. Changes in CK, PK and PCK for Male and Female Teacher Candidates 
This pattern of changes in CK, PK and PCK is the same as the results of research by Zaenal Abidin et al [2]. The results of the research by Anujit Patra1 \& Abhijit Guha [3] show that there is no significant difference between male and female geography teachers PCK. Likewise, research by B D Rahmani [4] shows that there is no difference in the responses of male and female teachers to the PCK questionnaire. However, changes in CK, PK and PCK based on gender are different when seen in the pattern of changes in each semester. Based on Figure 1, the average CK of female teacher candidates in semester 2 is higher than that of boys, while the CK of men is higher than that of women in semesters 4,6 and 8 . PK for men in semesters 2, 4 and 6, while PK for women in semester 8 is higher than PK for men. The average PCK for women was higher than that for men in semester 2, while the PCK for women was lower than that for men in semesters 4,6 and 8 . Based on this, there is an equation between the average CK and PCK based on gender, namely -The average CK and PCK of women was higher than that of men in semester 2 while in the following semester men were higher than the average CK and PCK of women. The results of the research by Mira Olivia HR, Tri Jalmo, and M. Setyorini [5] show that female teachers have a higher impact than male teachers on the PCK training instrument provided, namely women by $97.4 \%$ and men at 94.83 $\%$.

Based on the data on changes in CK, PK and PCK above, changes in CK, PK and PCK based on gender have similarities and differences. The similarity lies in the pattern of changes in CK, PK and PCK. The difference lies in the comparison of the level of mastery of CK, PK and PCK between male and female teacher candidates in each semester. The CK of male teacher candidates at the beginning of the semester is lower than that of female teacher candidates and is higher in the following semesters. The PK of male teacher candidates up to semester six is higher than female teacher candidates and semester eight is lower. The PCK for male teacher candidates is lower than female teacher candidates in the first semester and higher in the following semester.

The CK and PCK of male teacher candidates in the final semester were higher than female teacher candidates indicating that male teacher candidates had better understanding of content and PCK than female teacher candidates. This result contradicts the results of P.N. Diana and H.L. Mampouw [6] conducted a study on two junior high school math teachers, one male and one female, with the results of which female teachers have a higher level of understanding of mathematics material than female teachers. Likewise, PCK for women is better than PCK for men. Meanwhile the results of research on Technological Pedagogical and Content Knowledge (TPACK) on the Technological Content Knowledge (TCK) component showed the same results as this study, namely the ability of TCK or CK on PCK for male physics teachers was higher than female teachers [7].

The CK of male teacher candidates at the beginning of the semester is lower than the female teacher candidates and higher in the following semesters, indicating that the CK of female teacher candidates has a better provision of understanding when entering college, but female teacher candidates have slower growth than male teacher candidates. The results of research by Kathy Jordan [8] show that male beginner teachers have higher CK than women. The PK of male teacher candidates up to the sixth semester is higher than female teacher candidates and the eighth semester is lower indicating that the PK of male teacher candidates at the beginning of college lectures has strong PK curiosity and weakens towards the end of the course of study. The PCK for male teacher candidates was lower in the first semester and higher in the following semesters, indicating that at the beginning of the semester male teacher candidates had lower readiness to become a teacher than female teacher candidates. Along 
with the increase in knowledge and learning experience gained, the readiness of male teacher candidates is higher than female teacher candidates.

Based on the average score of the concept map as shown in Figure 2, the average score of the six semester male teacher candidate concept map $<$ four $<$ two $<$ eight. The average score of the sixth semester female teacher candidate's concept map $<$ two $<$ four $<$ eight. This means that there is a difference in the order of the concept map mean score between male and female teacher candidates, namely the second and fourth semester teacher candidates. The second semester male teacher candidates are higher than the fourth semester, while the female teacher candidates are the opposite. This also means that concept map knowledge is not directly proportional to the number of semesters taken by male and female teacher candidates. The data on the value of concept maps made by Biology teacher candidates show that both male and female prospective teachers have a complete understanding when they sit in the final semester. This also shows that the PCK for prospective teachers in the eighth semester is almost closer to the PCK which is complete and more complete when they are already teachers.

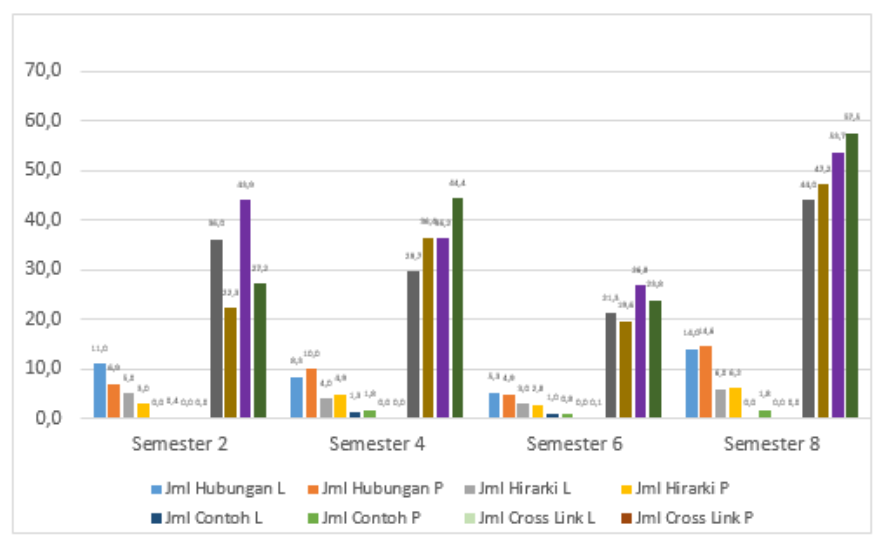

Fig 2. Changes in the Mastery of the Concept Map for Male and Female Teacher Candidates

Based on Figure 2, the order of the ability of male teacher candidates in determining the number of propositional relationships between semesters is the average value of male teacher candidates in semester six $<$ four $<$ two $<$ eight. The order of the ability of female teacher candidates in determining the number of propositional relationships between semesters is the mean score of female teacher candidates in semester six $<$ two $<$ four $<$ eight. The order of the ability of male teacher candidates in determining the hierarchy between semesters is the mean score of male teacher candidates in semester six $<$ four $<$ two $<$ eight. While the order of the ability of female teacher candidates in determining the hierarchy between semesters is the average score of female teacher candidates in semester six $<$ two $<$ four $<$ eight. The order of the ability of male teacher candidates in determining samples between semesters is the average score of male teacher candidates in semester two <eight $<$ six $<$ four. While the order of the ability of female teacher candidates in determining samples between semesters is the average score of female teacher candidates in semester two $<$ six $<$ four $<$ eight.

The largest contribution of concept map scores for both male and female teacher candidates came from the number of relationships (propositions), followed by hierarchical number, number of samples and cross-links, respectively. This means that the level of understanding of male and female teacher candidates on ecosystem balance material is at a basic level. The ability to cross-link the entire sample of 80 , only one of the six semester 
female teacher candidates. The data on the ability to make concept maps mentioned above are odd based on the number of semesters that have been taken, namely the fourth semester students are higher than the sixth semester students. In fact, one of the components of the concept map, namely the component determining the number of propositions of the sixth semester students lost to the second semester students, although the overall scores of the sixth semester students were higher than the second semester students and there were some sixth semester students who were able to make cross-links. Eighth semester students have the highest score; this indicates that eighth semester students are more thorough in understanding the concept of ecosystem balance.

However, if it is seen based on the concept map knowledge data as in Figure 2, then the eighth semester students have a higher average score than the semester students under them. The results of this study are in accordance with the results of research by Z. Abidin et al (11) that the mastery of concept maps changes form from simple concept maps to complex concept maps, more meaningful and easy to understand as propositions, and only important concepts emerge.

Based on the results of research on PCK and concept maps for male and female teacher candidates, it can be seen that both of them have different rates of change in PCK, namely men master PCK faster than women; changes in the concept map show that women have more consistent and regular changes in accordance with the increase in the number of semesters taken, while men have irregular changes. The results of other studies show that male teachers' PCK is lower than female based on the ability to make lesson plans through CoRe (Content Representation) and the ability to reflect learning outcomes through PaP-eRs (Pedagogical and Professional-experience Repertoires) made [10]. The results of research by Z. Abidin et al [11] show that PCK changes along with the increase in education and training experienced.

From the results of the answers to interviews conducted with male and female teacher candidates on the PCK development program during the lecture program, generally male teacher candidates answered simple and practical answers, while female teacher candidates answered in detail. When asked about the contribution of the lecture program to the development of PCK components, female teacher candidates explain in detail about each PCK component, namely 1) mastery of the curriculum of a scientific discipline (curricular knowledge), 2) recognizing learning styles and learning difficulties, 3) assessing conception students (preconceptions and misconceptions), 4) have a learning strategy according to the topic and condition of students, and 5) assess student learning outcomes. Male teacher candidates generally only stated that the lecture program they had been undergoing had contributed to the development of their PCK, while female teacher candidates explained the contribution of the lecture program to each PCK component in detail.

\section{Conclusion}

The profiles of changes in the PCK of male and female Biology teacher candidates have the same pattern of change, which is not linear with the number of semesters that have been taken. Both end in almost complete mastery of PCK when prospective teachers are in their eighth semester. Male Biology teacher candidate PCK has higher PCK than female PCK. The rate of change in the PCK of male Biology teacher candidates is faster than that of women. Changes in PCK for female teacher candidates are more consistent and regular than for men who have unequal changes. 


\section{References}

[1] Shulman, L S. 1986. Those Who Understand: Knowledge Growth in Teaching. Educational Researcher. Vol. 15. No. 2. pp. 4-14

[2] [2] Zaenal Abidin, Saiful Ridlo, Sri Mulyani ES, \& Andreas Priyono BP. 2020. Analysis of PCK Changes in Prospective Biology Teachers. International Journal of Psychosocial Rehabilitation. Vol. 24. Issue 03

[3] [3] Anujit Patra1 \& Abhijit Guha. 2017. Comparative Study on Geography Teachers' Pedagogical Content Knowledge (PCK) and Self-Efficacy in West Bengal, India. Quest Journals Journal of Research in Humanities and Social Science. Volume 5. Issue 3. pp: 68-71

[4] [4] B D Rahmani. 2018. Differential item functional analysis on pedagogic and content knowledge (PCK) questionnaire for Indonesian teachers using RASCH model. J. Phys.: Conf. Ser. 948012061

[5] [5] Mira Olivia HR, Tri Jalmo, and M. Setyorini. 2018. PCK in Science Education: Perception of Science Teacher on PCK Instruments. IOSR Journal of Research \& Method in Education (IOSRJRME). e- ISSN: 2320-7388.p-ISSN: 2320-737X Volume 8. Issue 4 Ver. IV. PP 37-44 www.iosrjournals.org

[6] [6] P.N. Diana dan H.L. Mampouw. 2019. Deskripsi Pedagogical Content Knowledge Guru Matematika Ditinjau dari Perdedaan Gender. Jurnal Cendekia: Jurnal Pendidikan Matematik. Volume 3. No. 1. pp. 47-57

[7] [7] M Masrifah, A Setiawan, P Sinaga and W Setiawan. 2018. Profile of senior high school inservice physics teachers' technological pedagogical and content knowledge (TPACK). J. Phys.: Conf. Ser. 1097012025

[8] [8] Naryanto. 2019. Hubungan kemampuan Pedagogical Content Knowledge (PCK) dengan latar belakang mahasiswa calon guru kimia. Skripsi: Fakultas Ilmu Tarbiyah dan Keguruan UIN Syarif Hidayatullah Jakarta.

Tersedia pada: http://repository.uinjkt.ac.id/dspace/handle/123456789/45449

[9] [9] Kathy Jordan. 2013. The influence of gender on beginning teachers' perceptions of their Technological Pedagogical Content Knowledge (TPACK). Australian Educational Computing. 28(2)

[10] [10] W Purwianingsih and A Mardiyah. 2018. Analysis of pedagogical content knowledge (PCK) ability of science teachers in planning and reflecting on environmental pollution content. J. Phys.: Conf. Ser. 1013012076

[11] [11] Z Abidin, S M E Susilowati, A P B Prasetyo, \& S Ridlo. 2019. The profile changes in pedagogical content knowledge of pre-service biology teachers based on the concept maps. J. Phys.: Conf. Ser. 1567042083 